\title{
GAMBARAN TINGKAT PENGETAHUAN REMAJA TENTANG INFEKSI MENULAR SEKSUAL DI SMK MANDIRI CIREBON
}

\author{
Sriyatin \\ Dosen Jurusan Keperawatan Poltekkes Kemenkes Tasikmalaya
}

\begin{abstract}
ABSTRAK
Beberapa survey di Indonesia menyimpulkan pengetahuan remaja tentang IMS masih rendah. Setelah dilakukan wawancara terhadap 10 responden didapatkan 2 siswa (20\%) dengan pengetahuan baik dan 8 siswa (80\%) dengan pengetahuan kurang tentang IMS. Penelitian ini bertujuan untuk mengetahui tingkat pengetahuan remaja tentang Infeksi Menular Seksual (IMS) di SMK Mandiri Cirebon dalam tingkat baik, cukup dan kurang berdasarkan usia dan sumber informasi. Desain penelitian ini menggunakan deskriptif kuantitatif. Penelitian di lakukan di SMK Mandiri Cirebon pada tanggal 07 April 2014. Populasi sejumlah 209 siswa. Teknik pengambilan sampel adalah total sampling. Variabel penelitian adalah variabel tunggal yaitu tingkat pengetahuan remaja tentang Infeksi Menular Seksual. Instrumen penelitian ini adalah kuesioner. Metode pengolahan dan analisa data menggunakan analisa univariat yang menghasilkan distribusi frekuensi dan persentase. Hasil penelitian tingkat pengetahuan remaja tentang Infeksi Menular Seksual di SMK Mandiri Cirebon sebagian besar memiliki tingkat pengetahuan kurang sebanyak 104 responden (55,0\%). Berdasarkan data tersebut dapat disimpulkan tingkat pengetahuan remaja tentang Infeksi Menular Seksual di SMK Mandiri Cirebon dapat dikategorikan tingkat kurang (55\%).
\end{abstract}

Kata Kunci : Pengetahuan, Remaja, Infeksi Menular Seksual

\begin{abstract}
Some of the results of the survey in Indonesia concluded that adolescent knowledge about STIs is low. Having conducted interviews with 10 respondents obtained 2 students (20\%) with good knowledge and 8 students (80\%) with less knowledge about STIs. This study aims to determine the level of knowledge of adolescents about sexually transmitted infections in SMK Mandiri Cirebon in a good level, pretty and less based on the age and source of information. This study design using quantitative descriptive. Independent research conducted in SMK Mandiri Cirebon on April 7, 2014. Population number of 209 students. The sampling technique is the total sampling. Research variable is a single variable, namely the level of knowledge of adolescents about sexually transmitted infections. The research instrument was a questionnaire. Methods of processing and analyzing the data using univariate analysis that generates a frequency distribution and percentages. The level of knowledge of adolescent research results about Sexually Transmitted Infections in SMK Mandiri Cirebon most have less knowledge level as 104 respondents (55,0\%). Based on these data we can conclude the level of knowledge of adolescents about sexually transmitted infections in SMK Mandiri Cirebon can be categorized levels less (55,0\%).
\end{abstract}

Keywords : Knowledge, Adolescent, Sexually Transmitted Infections

\section{PENDAHULUAN}

Fenomena medis yang sangat menarik pada saat ini adalah infeksi menular yang ditularkan melalui hubungan seksual. Berdasarkan penelitian WHO pada tahun 2005 tercatat 448 juta kasus baru Infeksi Menular Seksual (IMS) yang terjadi pada orang dewasa berusia 15 - 49 tahun. Angka ini tidak termasuk penyakit HIV dan IMS lainnya yang terus berlangsung dan mempengaruhi kehidupan individu dan masyarakat di dunia.

Di Indonesia sendiri prevalensi perkembangan IMS cukup tinggi terbukti dari Laporan Survei Biologis dan Perilaku (LSBP) 
Kemenkes RI pada tahun 2011 mencatat $43 \%$ waria, $56 \%$ waria pekerja seks langsung, $68 \%$ homoseks dan $35 \%$ waria pekerja seks tidak langsung terkena infeksi klamidia dan $3 \%$ penasun (pengguna napza suntik), $27 \%$ waria, $4 \%$ homoseks terkena infeksi sifilis.

Penelitian tentang pengetahuan IMS yang dilakukan di DKI Jakarta oleh Lembaga Demografi-UI pada 2005 menunjukkan, pengetahuan remaja mengenai berbagai jenis IMS masih sangat rendah, kecuali pengetahuan mereka mengenai penyakit HIV/AIDS dan Sifilis. Sebanyak 95\% remaja sudah mengetahui mengenai penyakit menular seksual

Hasil survey dari Badan Koordinasi Keluarga Berencana Nasional (BKKBN) pada

Fakta yang peneliti temukan pada sebuah institusi pendidikan di wilayah Cirebon pada tahun 2013 yaitu terdapat 11 siswa dikeluarkan dari sekolah karena pelanggaran norma asusila yakni melakukan hubungan seksual yang dilakukan dilingkungan sekolah. Hal tersebut menandakan bahwa rendahnya pengetahuan siswa tersebut mengenai pengetahuan seksual yang akan berisiko terkena IMS.

Berdasarkan hasil studi pendahuluan yang peneliti lakukan di SMK Mandiri Kota Cirebon pada tanggal 04 Januari 2015 dengan melakukan pendekatan wawancara kepada kepala sekolah dan guru BK setempat menyatakan bahwa pada semester I sempat diadakan program penyuluhan tentang narkoba dan seks education pada seluruh siswa Yayasan Mukti Mandiri Cirebon. Namun pada semester II sekarang tidak ada program serupa karena keterbatasan narasumber yang memberikan materi penyuluhan. Selain itu sekolah tidak mempunyai program khusus yang dijalankan secara rutin untuk memberikan pendidikan diluar konteks pelajaran yang siswa pelajari di sekolah seperti seks education, khususnya tentang IMS, kesehatan reproduksi, dan bahaya narkoba.

Saat peneliti menanyakan kepada guru BK perihal adakah siswa yang menjalin hubungan dekat seperti berpacaran dan seperti apa pola pacaran mereka, beliau bulan Mei tahun 2002 terhadap 2880 respoden usia 15-24 tahun di enam kota di Jawa Barat menunjukkan bahwa 39,65\% respoden pernah melakukan hubungan seks pranikah. Bahkan hasil polling terhadap 200 mahasiswa sebuah perguruan tinggi di bandung menunjukkan bahwa $50 \%$ responden telah melakukan hubungan badan 1 kali dan 20\% lebih dari 2 kali. Fenomena ini menunjukkan bahwa perilaku remaja di berbagai kota di Indonesia menunjukkan perilaku yang sama. Akibat yang disebabkan oleh pergaulan bebas dan seks pranikah adalah kehamilan yang tidak diinginkan, penyakit menular seksual serta HIV-AIDS (widjanarko, 2002).

mengetakan ada sebagian siswa yang pacaran di sekolah ini baik dengan sesama temannya disekolah maupun dari luar sekolah, namun beliau tidak begitu mengetahui bagaimana pola dan sejauh mana hubungan yang mereka jalani karena hal tersebut merupakan privasi mereka. Sesekali mereka datang ke BK untuk bercerita seputar masalah-masalah yang mereka hadapi dengan keluarga, teman sekolah, masalah proses belajar di sekolah dan hubungan sosial yang mereka jalin bersama orang lain.

Selain melakukan wawancara peneliti juga menyebarkan angket kepada 10 siswasiswi yang berisi lima pertanyaan tentang IMS. Hasilnya dari 10 siswa-siswi yang memiliki pengetahuan baik tentang IMS dengan skor $>75$ hanya $20 \%$ dan $80 \%$ memiliki skor $<60$ yang masuk kategori pengetahuan kurang. $\mathrm{Hal}$ tersebut membuktikan bahwa pengetahuan siswasiswi remaja SMK Mandiri tentang IMS masih kurang.

Dari data dan fakta di atas, jelas bahwa IMS telah menjadi problem tersendiri bagi pemerintah. Tingginya angka kejadian IMS di kalangan remaja dan dewasa muda, merupakan bukti bahwa masih rendahnya pengetahuan remaja akan IMS. Hal ini mungkin disebabkan masih kurangnya penyuluhan-penyuluhan yang dilakukan oleh pemerintah dan badan-badan kesehatan 
lainnya. Tidak adanya mata pelajaran yang secara khusus mengajarkan dan memberikan informasi bagi murid sekolah, juga menjadi

\section{METODE PENELITIAN}

Jenis penelitian yang digunakan adalah metode deskriptif kuantitatif. Lokasi penelitian dilakukan di institusi pendidikan SMK Mandiri Cirebon. Populasinya adalah seluruh siswa di SMK Mandiri Cirebon yang berjumlah 209 siswa. Teknik pengambilan sampel adalah total sampling yaitu semua anggota populasi yang memenuhi kriteria inklusi dijadikan sampel. Kriteria inklusinya yaitu siswa yang hadir di sekolah, dan bersedia menjadi responden.

\section{HASIL PENELITIAN}

Berdasarkan karakteristik responden menurut jenis kelamin menunjukkan bahwa distribusi frekuensi jenis kelamin remaja di SMK Mandiri Cirebon yaitu laki-laki dengan persentase $55 \%$ dan perempuan dengan persentase $45 \%$. Data tersebut menunjukkan bahwa jumlah laki-laki lebih banyak dari pada perempuan. Berdasarkan usia dari responden menunjukkan bahwa distribusi frekuensi usia remaja di SMK Mandiri Cirebon didominasi oleh remaja madya (15-17 tahun) dengan persentase $84,7 \%$.

Hasil penelitian distribusi frekuensi tingkat pengetahuan remaja tentang IMS di SMK Mandiri Cirebon mayoritas termasuk

\section{PEMBAHASAN}

Pengetahuan responden berada pada tingkat tahu dan memahami sebab kuesioner dalam penelitian ini hanya dapat mengukur tingkat pengetahuan responden sampai dengan tingkat tahu dan memahami. Pengetahuan diperoleh dari informasi baik lisan maupun tulisan dari pengalaman seseorang. Pengetahuan responden diperoleh dari fakta dengan melihat dan mendengar sendiri melalui alat komunikasi seperti melihat film atau televisi, membaca surat kabar, mendengarkan radio dan lainlain. salah satu penyebab tingginya angka kejadian IMS di kalangan remaja.

Variabel penelitian ini adalah variabel tunggal yaitu tingkat pengetahuan. Peneliti menggunakan instrumen pengumpulan data dalam bentuk kuisioner. Sebelum instrumen tersebut digunakan terlebih dahulu dilakukan uji instrumen di SMK 1 Kedawung pada 30 responden. Analisa data yang dilakukan yaitu analisa univariat untuk mengetahui distribusi frekuansi dari variabel penelitian.

kategori kurang (55\%), hasil yang didapat dari sumber informasi mayoritas didominasi oleh media cetak/elektronik (51,9\%). Data tingkat pengetahuan remaja tentang IMS berdasarkan usia didominasi oleh remaja madya (15-17 tahun) yang memiliki pengetahuan baik 2 orang, pengetahuan cukup 71 orang, dan pengetahuan kurang 87 orang dan dapat disimpulkan bahwa sumber informasi yang paling banyak digunakan oleh remaja di SMK Mandiri Cirebon untuk mendapatkan informasi tentang IMS adalah melalui media cetak/elektronik $(51,8 \%)$ dan yang paling sedikit adalah melalui keluarga $(2,6 \%)$.

Berdasarkan pengamatan terhadap
sikap seksual remaja saat ini, diperlukan
identifikasi terhadap kebutuhan untuk
meningkatkan pengetahuan siswa melalui
pendidikan kesehatan reproduksi remaja
termasuk pendidikan seksual dalam rangka
melindungi siswa dari sikap seksual yang
berbahaya. Beberapa penelitin menunjukkan
bahwa pendidikan seks dapat membatu
menunda terjadinya hubungan seksual yang
pertama untuk remaja yang belum aktif
seksual, sedangkan untuk remaja yang telah
aktif seksual, pendidikan seks dapat
mendorong pemakaian kontrasepsi atau


pencegaha penyakit menular seksual secara tepat dan konsisten.

Implikasi dari hasil penelitian ini memberikan informasi lebih kepada tenaga kesehatan dalam hal ini adalah perawat, mengenai gambaran tingkat pengetahuan remaja tentang infeksi menular seksual dimana IMS pada saat ini sedang menjadi sorotan publik karena saat ini banyak kasus pelecehan seksual terhadap anak atau remaja yang berisiko menimbulkan infeksi

\section{KESIMPULAN}

Tingkat pengetahuan remaja tentang IMS di SMK Mandiri Cirebon sebagian besar kurang $(55 \%)$, sebagian besar remaja termasuk dalam kategori usia remaja madya

\section{REFERENSI}

Arikunto S., (2006). Prosedur Penelitian Suatu Pendekatan Praktik. Jakarta: Rineka Cipta.

Artikel, (2004). Sikap dan perilaku remaja. http://www.cerminduniakedokteran.com diakses pada tanggal 12 Mei 2014.

Fatimah, dkk., (2009). Membuat Usulan Proposal KTI dan Laporan Hasil KTI. Jakarta: CV. Trans Info Media.

Fahmi, D.S., (2007). Infeksi Menular Seksual. Jakarta: Fakultas Kedokteran UI. , (2011). Infeksi Menular seksual. Jakarta: Fakultas Kedokteran UI.

Hadi, et al,. (2008). Pengetahuan, sikap dan perilaku remaja jakarta tentang seks aman dan faktor yang berhubungan. Jakarta: FK Universitas Pembangunan Nasional.

Hidayat, A. Dan Aziz A., (2007). Metode penelitian keperawatan dan teknik analisa data. Jakarta: Salemba Medika.

Kemenkes RI., (2006). Pencegahan dan Penularan HIV/AIDS \& IMS. diakses pada 03 Oktober 2013 dari www.depkes.go.id (2011). Prevalensi IMS. Diakses pada 03 Oktober 2013 dari www.depkes.go.id. Kusmiran, E., (2011). Kesehatan Reproduksi Remaja dan Wanita. Jakarta: Salemba Medika. menular seksual. Bukan hanya kasus pelecehan seksual tetapi juga banyak remaja yang berperilaku seksual tidak sesuai dengan perkembangan seusianya. Hal tersebut dapat dijadikan pertimbangan untuk membuat suatu program kesehatan reproduksi dari instansi kesehatan atau dinas kesehatan setempat untuk mengoptimalkan pemberian asuhan keperawatan khususnya terhadap kalangan remaja

memiliki pengetahuan tentang IMS kurang dan sebagian besar remaja memperoleh sumber informasi mengenai IMS melalui media cetak dan elektronik.

Merati, T.P., (2004). Buku Ajar Ilmu Penyakit Dalam. Jakarta: Balai Penerbit FKUI.

Mubarak, W.I., (2011). Promosi Kesehatan Untuk Kebidanan. Jakarta: Salemba Medika.

Nirwana, A.B., (2011). Psikologi lbu, Bayi dan Anak. Yogyakarta: Nuha Medika.

Notoatmodjo, S., (2005). Metode Penelitian Kesehatan. Jakarta: Rineka Cipta. (2007). Promosi Kesehatan dan Perilaku. Jakarta: Rineka Cipta.

Notobroto, H.B., (1999). Pengetahuan dan Sikap Siswa SMU dan Guru Bimbingan Konseling di Jawa Timur terhadap Penyakit Menular Seksual dan AIDS. Diakses dari : http://www.adln.lib.unair.ac.id Diakses pada tanggal 4 Juni 2014.

Pieter, Herri Z., \& Lubis N.L., (2010). Pengantar Psikologi Untuk Kebidanan. Jakarta: Kencana.

Prihyugiarto, T.Y., (2008). Faktor-faktor yang Mempengaruhi Sikap Terhadap Perilaku Seks Pranikah pada Remaja di Indonesia. Dalam :Jurnal IImiah Keluarga Berencana dan Kesehatan Reproduksi . Diperoleh dari : http://www.bkkbn.go.id. Diakses pada tanggal 4 Juni 2014. 
Roumauli, Suryati \& Vindari, A.V,. (2009). Kesehatan Reproduksi Untuk Mahasiswa Kebidanan. Yogyakarta: Nuha Medika.

Sarwanto, A.S., (2004). Pengetahuan, Sikap, dan Perilaku Pekerja Remaja terhadap Penyakit Menular Seksual serta Faktorfaktor yang Mempengaruhi Terjadinya hubungan Seks Pranikah. Diperoleh dari: http://www.kalbe.co.id Diakses pada Tanggal 4 Juni 2014.
Sarwono, Sarlito Wirawan. (2010). Psikologi Remaja. Jakarta: Rajawali Pers. (2001). Psikologi Remaja. Yogyakarta: Alenia press.

Wiraharja, R.S., (2003). Kesehatan Reproduksi. Jakarta: UI.

Widjanarko, (2002). Artikel, konsep informasi reproduksi remaja. diakses pada tanggal 20 Januari 2014 dari http://www.pikiranrakyat.com. 